\title{
Exchange Rate Dynamics and the Disconnect ${ }^{\#}$
}

\author{
Miroslava Jindrová*
}

Since the fall of Bretton-Woods system in 1970s and the introduction of floating exchange rates, the exchange rates have in some cases become "extremely volatile" without no corresponding link to changes in its "macroeconomic fundamentals". This has led to higher interest in exchange rate modelling as the question of exchange rate determination reveals to be one of the most important problems on theoretical field of monetary macroeconomics. Structural monetary models have been introduced and used in exchange rate modelling in a quite successful way in the early 1970s, especially when concerning within-sample comparisons. However, hand to hand to this "boom" of exchange rate determination theory, several empirical "puzzles" have revealed during the time. The nice overview of the six major puzzles in the international macroeconomics can be found for example in Obstfeld and Rogoff (2000) ${ }^{1}$. The last two mentioned puzzles there are the so called purchasing power parity and "disconnect puzzle", both "price anomalies" dealing with the fact that the exchange rate movements doesn't respond "consistently" to the movements of the underlying macroeconomic fundamentals, e.g. according to their theoretic values and directions. In fact, the term "disconnect puzzle" refers to several different phenomena in the exchange rate modelling literature.

\section{Introduction}

The exchange rate "disconnect puzzle" in a sense of Obstfeld and Rogoff (2000) is a missing link between exchange rates and the macroeconomic fundamentals that international macroeconomics theory suggests should be the driving force of the exchange rates. In particular, it seems that macroeconomic variables are not able to explain not only a current level of exchange rates but even their volatility. It should be mentioned that the "disconnect puzzle" in this meaning is a general term that includes also another well known puzzles: "forward bias puzzle" and "purchasing power parity puzzle".

In fact, however, the so called "exchange rate disconnect puzzle" refers to two different phenomena in the exchange rate literature: whereas the first refers to "exchange rate determination puzzle", i.e. the fact, that exchange rate can not be

\footnotetext{
The support from the Czech Science Foundation under the Grant 402/03/H057 is gratefully acknowledged. Ing. Miroslava Jindrová - doctoral student; Department of Monetary Theory and Policy, Faculty of Finance and Accounting, University of Economics, Prague, nám. W. Churchilla 4, 13067 Prague 3, Czech Republic; <jindrovm@vse.cz>.

1 For the review of six empirical international puzzles see for example Obstfled (2000). (the home bias in trade puzzle, Feldstein and Horioka puzzle, the home bias portfolio puzzle and the low consumption correlation puzzle, the purchasing power parity puzzle, the exchange rate disconnect puzzle).
} 
explained by the corresponding movement in macroeconomic fundamentals. ${ }^{2}$ This puzzle was firstly established by Meese and Rogoff in 1983, when they have published their influential paper concerning out-of-sample forecasting accuracy of the standard macroeconomic models. They found that no so far known monetary model is able to outperform a naive random walk model of exchange rate. A second part of the puzzle ${ }^{3}$ refers to extreme (or excessive) volatility of exchange rates with respect to other macroeconomic fundamentals. This second part concerns two concepts of extreme volatility of exchange rates: the excessive volatility under the given exchange rate regime (e.g. the fact that floating exchange rates are more volatile than the corresponding fundamentals) on the one hand, and the excessive volatility when moving from one exchange rate regime to another.

The rough insight into the problem of "exchange rate determination" puzzle gives us the following table about the variability of some key macroeconomic fundamentals in the CR.

Table 1: Standard deviations, 1993 - 2006 (where available) of the growth rates of fundamentals

\begin{tabular}{|c|c|c|c|c|c|c|c|}
\hline $\begin{array}{c}\text { Standard } \\
\text { deviation }\end{array}$ & $\Delta\left(m_{t}-m_{t}^{*}\right)$ & $\Delta\left(i_{t}-i_{t}^{*}\right)$ & $\Delta\left(y_{t}-y_{t}^{*}\right) *$ & $\begin{array}{c}\Delta s_{t}^{d} \\
\text { EUR/CZK } \\
\text { end) }\end{array}$ & $\begin{array}{c}\Delta s_{t}^{d} \\
\text { (EUR/CZK } \\
\mathbf{a v g})\end{array}$ & $\begin{array}{c}\Delta q_{t}^{d *} \\
(\mathbf{E U R / C Z K} \\
\mathbf{e n d})\end{array}$ & $\begin{array}{c}\Delta q_{t}^{d} * \\
\text { (EUR/CZK } \\
\mathbf{a v g})\end{array}$ \\
\hline $\begin{array}{c}\text { whole } \\
\text { sample }\end{array}$ & 0.0125 & 0.0392 & 0.0641 & 0.0520 & 0.0393 & 0.0522 & 0.0662 \\
\hline $\mathbf{1 9 9 6}$ & 0.0159 & 0.0338 & 0.1114 & 0.0291 & 0.0234 & 0.0364 & 0.0470 \\
\hline $\mathbf{1 9 9 7}$ & 0.0117 & 0.0820 & 0.1499 & 0.0825 & 0.0609 & 0.0714 & 0.0926 \\
\hline $\mathbf{1 9 9 8}$ & 0.0117 & 0.0150 & 0.0326 & 0.1001 & 0.0484 & 0.0679 & 0.1130 \\
\hline $\mathbf{1 9 9 9}$ & 0.0123 & 0.0594 & 0.0311 & 0.0691 & 0.0591 & 0.0796 & 0.0943 \\
\hline $\mathbf{2 0 0 0}$ & 0.0102 & 0.0276 & 0.0438 & 0.0308 & 0.0306 & 0.0386 & 0.0402 \\
\hline $\mathbf{2 0 0 1}$ & 0.0125 & 0.0245 & 0.0252 & 0.0352 & 0.0276 & 0.0309 & 0.0389 \\
\hline $\mathbf{2 0 0 2}$ & 0.0151 & 0.0205 & 0.0507 & 0.0574 & 0.0548 & 0.0591 & 0.0620 \\
\hline $\mathbf{2 0 0 3}$ & 0.0120 & 0.0249 & 0.0368 & 0.0308 & 0.0236 & 0.0359 & 0.0377 \\
\hline $\mathbf{2 0 0 4}$ & 0.0103 & 0.0137 & 0.0258 & 0.0456 & 0.0282 & 0.0242 & 0.0414 \\
\hline $\mathbf{2 0 0 5}$ & 0.0115 & 0.0201 & 0.0116 & 0.0331 & 0.0299 & 0.0297 & 0.0334 \\
\hline $\mathbf{2 0 0 6}$ & 0.0119 & 0.0112 & 0.0303 & 0.0270 & 0.0201 & 0.0298 & 0.0362 \\
\hline
\end{tabular}

Source: own computation (normalized time series, in log deviations)

* Data available since 1/1996, $\Delta\left(m_{t}-m_{t}^{*}\right)$ is the money stock differential growth, $\Delta\left(i_{t}-i_{t}^{*}\right)$ is the interest rate differential, $\Delta\left(y_{t}-y_{t}^{*}\right)$ is the output growth differential (using industry as a proxy), $\Delta s_{t}^{d}$ is the nominal exchange rate growth and $\Delta q_{t}^{d}$ is the real exchange rate. See Appendix for more details about the variability of macroeconomic fundamentals.

Those data brings us quite surprising insight: even when there were several different monetary policy regimes during the last decade in the CR, the variability of the growth of the important macroeconomic fundamentals differentials remains (roughly

\footnotetext{
2 The out of sample accuracy of traditional monetary models in Meese and Rogoff (1983) refers to this part of the "disconnect". Another disconnect literature could be found in Campbell (2006); Cheung - Chinn - Pascual (2005); Engel - West (2005); Flood - Rose (1999) and Sarno (2005).

3 Much closer to what Obstfeld and Rogoff have identified.
} 
said) unchanged ${ }^{4}$, except for the pre- and post-crisis period, where, however, the money growth differential stays stable too. That fact can't be interpreted as the evidence for disconnect, but on the other hand, these findings seems to be quite surprising.

The aim of this paper is to summarize two directions of the research relating to this "puzzle", i.e. which aspects of these puzzles are those approaches able to solve, where are their limits, and where further research interest is most likely to turn.

\section{Searching for Explanations of a "Disconnect Puzzle"}

As this puzzle is undoubtedly controversial, several directions of possible explanations have revealed over time. One problem about the international macroeconomics is straightforward: the stylized fact revealed in empirical research is that the three key assumptions in standard monetary models do not hold: short term and sometimes even long run deviations of purchasing power parity, miserably performed uncovered interest parity and unstable money demand equations generally - this all together might be the cause of the "disconnect puzzle". But even if this would be the case, question why it is so still remains. Another open issue is whether the Dornbusch type overshooting ${ }^{5}$ might be responsible for the ,disconnect puzzle".

\section{Models Based on Obstfeld and Rogoff (1995)}

The first direction of the research tries to learn about disconnect from studying sticky price model based on Obstfeld and Rogoff's (1995). As was mentioned in the introduction, in the case of exchange rate disconnect it seems, that there is only a limited feedback not only with price levels, but either with other current macroeconomics variables, such as money supply of GDP, so that "exchange rates have lives of their own" and traditional exchange rate models have failed when trying to forecast short to medium exchange rate movements even ex-post. In order to get closer to answers to those questions, it would be necessary to modify the baseline Obstfeld and Rogoff model in several directions.

This sort of model is based on a dynamic general equilibrium (DGE) framework with well specified micro foundations, which allows for incorporating the assumptions of imperfect competition, incomplete asset markets and alternative pricing adjustments (as well as different types of nominal rigidities). The original model of Obstfeld and Rogoff does not allowed for the CPI-based deviations of purchasing power parity, as it assumes all goods to be tradables and complete pass-through of exchange rate changes to import prices (e.g. prices of tradables are set in buyer's currency). In the appendix to the Obstfeld-Rogoff (1995) is, however, sketched the small open economy version of their model, where the presence of nontraded consumption goods allows for the deviations of the purchasing power parity. Thus this makes exchange rate overshooting possible. Because of the fact that their model could be taken as a benchmark to any other small scale open economies, we introduce it here.

Similar to any other DGE model, we assume that there is a continuum of consumer-producers that produce nontradable goods and consume both, the nontradables and the tradables. Each representative household is consider to have

\footnotetext{
See Appendix for the graphical exposition of the variability of macroeconomic fundamentals.

Exchange rate overshooting phenomenon was firstly introduced by Dornbusch (1976).
} 
monopoly over production of one of the nontradables $z \in[0,1]$ and is endowed a constant quantity of the traded good each period, $\bar{y}_{T}$,

The representative household $j$ seeks to maximize lifetime utility function of the form $U=E_{0}\left(\sum_{s=t}^{\infty} \beta^{s-t} u_{t}\right)$, which on their setup takes following particular form

$U_{t}^{j}=\sum_{s=t}^{\infty} \beta^{s-t}\left(\gamma \log C_{T, s}^{j}+(1-\gamma) \log C_{N, s}^{j}+\frac{\chi}{1-\varepsilon} \log \left(\frac{M_{s}^{j}}{P_{s}}\right)^{1-\varepsilon}-\frac{\kappa}{2} y_{N, s}(j)^{2}\right)$,

where $0<\beta<1$ is the discount factor, $C_{T}$ stands for consumption of the traded good and $C_{N}$ is nontraded goods consumption index defined by

$$
\left.C_{N}=\left\{\int_{0}^{1}\left[c_{N}(z)\right]\right]^{\theta-1} \theta\right\}^{\frac{\theta}{\theta-1}}
$$

Note that real balances enter utility function (eq. 1) directly and as a consequence of having general isoelastic function additively. Obstfeld and Rogoff (1995) showed, that the parameter $\varepsilon$ is the critical determinant of whether overshooting can occur or not. The CPI index $P$ in eq. (1) is defined by

$$
P \equiv P_{T}^{\gamma} P_{N}^{1-\gamma} / \gamma^{\gamma}(1-\gamma)^{1-\gamma},
$$

where $P_{T}$ is the price of tradables. It is assumed that the law of one price holds only in tradables, so that we can write $P_{T}=E \cdot P_{T}^{*}$ ( we consider the foreign price level $P_{T}^{*}$ as exogenous and constant). The nontraded goods price index $P_{N}$ is given by

$$
P_{N}=\left\{\int_{0}^{1}\left[p_{N}(z)\right]^{1-\theta} d z\right\}^{\frac{1}{1-\theta}}
$$

where $p_{N}(z)$ being the price of nontraded good $z$ in money terms. As a consequence of given preferences it is assumed that the demand curve for nontraded goods is downward sloping and has the form

$$
y_{N}^{d}(j)=\left[\frac{p_{N, t}(j)}{p_{N, t}}\right]^{-\theta} C_{N}^{A}
$$

$C_{N}^{A}$ is aggregate per capita nontraded goods consumption, here taken as a given. As bonds are denominated in tradables and $r$ denotes the constant world net interest rate in tradables and $\beta(1+r)=1$, the typical $j$ 's period budget constraint in money terms is defined as

$$
\begin{aligned}
P_{T, t} B_{t}+M_{t}+P_{N, t} C_{N, t}+P_{T, t} C_{T, t}= & P_{T, t}(1+r) B_{t-1}+M_{t-1} \\
& +p_{N, t}(z) y_{N, t}(z)+P_{T, t} \bar{y}_{t}+P_{t} \tau_{t}
\end{aligned}
$$


where per capita taxes $\tau$ are denominated in tradables.

Since Obstfeld and Rogoff assume that Ricardian equivalence holds, they abstract from government spending and introduce balanced government budget in each period. The government budget constraint, in units of tradables, is therefore given by

$$
\tau_{t}=\frac{M_{t}-M_{t-1}}{P_{T, t}}
$$

\section{Optimality Conditions}

By choosing the optimal level of consumption, money and bond holdings and the output of nontraded goods, the individuals solves their intertemporal maximization problem. In particular, first order conditions are found by maximizing eq. (1) with respect to constraints given by eq. (5) and (6). After doing some algebraic calculations, we get

$$
\begin{aligned}
& C_{T, t+1}=C_{T, t}, \\
& C_{N, t}=\frac{1-\gamma}{\gamma}\left(\frac{P_{T, t}}{P_{N . t}}\right) C_{T, t}, \\
& \frac{M_{t}}{P_{t}}=\left[\frac{\chi \cdot P_{T, t} C_{T, t}}{\gamma P_{t}}\left(\frac{1+i}{i}\right)\right]^{1 / \varepsilon}, \\
& y_{N, t}(j)^{(\theta+1) / \theta}=\left[\frac{(\theta-1)(1-\gamma)}{\theta \kappa}\right] C_{N, t}^{-1}\left(C_{N}^{A}\right)^{1 / \theta} .
\end{aligned}
$$

The term $i$ stands for nominal interest rate and is defined by the Fisher identity $1+i=(1+r) P_{T, t+1} / P_{T, t}$ Equation (8) is the so called Euler equation resolving optimal intertemporal allocation of tradables, whilst eq. (9) governs the optimal intratremporal levels of consumption of nontradables and tradables. Equation (10) is the money market equilibrium condition, where the money demand is the positive function of consumption and negative function of the interest rate. Equation (11) is the optimal labour-leisure choice where the marginal disutility of producing one extra unit of a nontraded goods is equal the marginal utility of consuming one.

Following Obstfeld and Rogoff $(1995)^{6}$, we derive the symmetric steady state in which all exogenous variables are constant and the initial level stock of net foreign assets is zero. Then the model is solved for log-linearized deviations of initial steady state. One can derive, that the equation for the long run equilibrium level of exchange rate, money supply and price level is (the variables with overbars/hats stands for loglinear deviation of initial steady state).

$$
\hat{P}_{T}=\hat{E}=\frac{\beta+(1-\beta) \varepsilon}{\beta+(1-\beta)(1-\gamma+\gamma \varepsilon)} \hat{M} .
$$

As long as law of one price holds only for tradables in small open economy manner, the price of traded goods changes in proportion to the exchange rate.

\footnotetext{
${ }^{6}$ For details of derivation of steady state see Appendix to Obstfeld - Rogoff (1995).
} 
From eq. (13) we see that, if $\varepsilon>1$, the nominal exchange rate overshoots its long run level. Why does it hold? When thinking of the term $1 / \varepsilon$ as being the consumption elasticity of money demand, one can imagine what happen if the situation is different from that when $\hat{P}_{T}=\hat{M}$ (i.e. when there is neither over- nor undershooting). If for example the supply of real balances would have to rise by $\hat{M}-\hat{P}=(1-\gamma) \hat{M}$, it can be derived that in this case the demand for real balances will rise by $(1 / \varepsilon)(1-\gamma) \hat{M}$. This means that when $\varepsilon>1$, the demand for real balances will rise by less than the supply and the price of tradables (the exchange rate) would have to rise further to reach equilibrium. Therefore the exchange rate overshoots its long run equilibrium level.

There is now a huge literature extending the OR model, usually referred to as the New Open Economy Macroeconomics. While Obstfeld and Rogoff (1995) assume complete pass through of exchange rates to prices because they assume that nominal prices are set in the currency of the producer, a lot of their successors have extended their framework to the local currency pricing (LCP) case ${ }^{7}$. The assumption of LCP has become one of the strongest competing explanation of the "disconnect puzzle", because this explanation of excessive exchange rate volatility concerns the behaviour of tradables' prices. Under LCP firms set prices in their own currency for sale to households located in their country, but set a price in foreign currency for sales to foreign households. They believe that within this framework it is possible to study and learn much more about the nature of exchange rate volatility when moving from one exchange rate regime to another. For example Duarte and Stockman (2005) came out with a modified version of Obstfeld and Rogoff (1995), when assuming the concept of goods market segmentation, local-currency pricing to market, incomplete asset markets and autonomous changes in risk premium that have been incorporated into the model.

However, the common feature of the models of this kind is (as similar to classic Dornbusch model) the so called "indeterminacy" of the steady state. This means that the time path of exchange rate dynamics will depend on the initial conditions. The fact that in model of that kind the exchange rate is indeterminate made the potential policy implications, which arise from that kind of models quite questionable.

\section{Models Build Upon Non-rational Behaviour of Economic Agents}

Another group of researchers is trying to answer the question of excessive volatility in resignation to rationality of agents' behaviour in exchange rate modelling and explore models with heterogeneous agents' structure starting from the microstructure of the foreign exchange market. This approach represents quite huge departure from traditional macroeconomic approach relaxing its key underlying assumptions.

We can mention Devereux and Engel (2002) among others, who believes that there are swings in expectations about future values of the exchange rates that stand behind so volatile exchange rates, which are (in his view) unrelated to prices and interest differentials. There are several issues that support his view: the fact that exchange rate expectations are inconsistent and seem to fail in forecasting future values, the failure of UIP that could be due to the non-rational behaviour of economic agents, failing of efficient market hypothesis. Last but not least, issues arising from switching from one

\footnotetext{
${ }^{7}$ Alternative assumptions of international pricing are to be found in Duarte (2001).
} 
exchange rate regime or monetary policy framework to another, which is generally followed by the changing of the way how expectations in the economy is made.

Under fixed exchange rate regime the government is obliged to stabilize the exchange rate at some predefined value. Countries moving from fixed to floating exchange rates face a remarkable change in the behaviour of real exchange rates ${ }^{8}$. They are much more volatile under floating exchange rate regimes, where expectations are not tied down by the threat of potential central bank intervention. However under the assumption that expectations are based on fundamentals, the relationship between fundamentals and exchange rates should be the same if there is no corresponding change in underlying fundamentals.

One non-rational direction of resolving exchange rate determination puzzle is the introduction of irrational behaviour of one group of agents in the foreign exchange market. The representative "non-rational" approach is for example the model with interaction of "chartists and fundamentalists", where agents have different beliefs about the future changes of exchange rates. The simple "chartists-fundamentalists" model could have for example following structure: Fundamentalists' excess demand depends on the deviations between the current exchange rate and its fundamental value ${ }^{9}$

$$
E D_{F}=\gamma\left(s_{f}-s_{t}\right)
$$

where $\alpha$ is the coefficient for the sensitivity to deviations of $s_{f}$ and $s_{t}$.

The chartists' excess demand will generally depend on the expectations over future depreciation of the exchange rate, i.e. on the expected future change of the exchange rate. $^{10}$

$$
E D_{C H}=\alpha \cdot\left(E_{t}\left[p_{t+1}\right]-p_{t}\right)=\alpha \cdot E\left(\dot{s}_{t}\right)=\alpha \cdot r_{t}
$$

where $\gamma$ is again the sensitivity parameter.

The depreciation of the exchange rate (the change of the exchange rate) is the outcome of the overall excess demand, as well as interaction between the agents:

$$
\dot{s}_{t}=\lambda\left(E D_{F}+E D_{C H}\right)=\lambda\left(\gamma\left(s_{f}-s_{t}\right)+\alpha \cdot E\left(\dot{s}_{t}\right)\right) \text {. }
$$

Under the assumption that chartists adjust their expectations adaptively to actual change in exchange rate, i.e. that

$$
\dot{r}_{t}=\beta\left(\dot{s}_{t}-r_{t}\right)
$$

where $\beta$ is the speed of adjustment of adaptively made expectations. Their behaviour may be like this due to lack of experience, which leads to their irrational behaviour.

The non-rational behaviour of agents is the consequence of chartists' adaptive expectations on one hand and the neglecting of the existence of chartists by fundamentalist on the other hand.

The previous equations constitute following system of two differential equations:

8 See Appendix for the evidence in the case of the CR.

9 This value might be given by PPP value as an example; it is the fundamental value that should be known to the fundamentalists. The chartist and fundamentalists approach was introduced by Frankel and Froot (1986)

10 In continuous time setting the difference between expected and the actual exchange rate can be replaced by the expected differential of exchange rate with respect to time. 


$$
\begin{aligned}
& \dot{s}_{t}=\lambda\left(\gamma\left(s_{f}-s_{t}\right)+\alpha \cdot r_{t}\right), \\
& \dot{r}_{t}=\beta\left(\dot{s}_{t}-r_{t}\right)=\beta\left(\lambda\left(\gamma\left(s_{f}-s_{t}\right)+\alpha \cdot r_{t}\right)-r_{t}\right) .
\end{aligned}
$$

Under dynamic equilibrium both $\dot{s}_{t}=0$ and $\dot{r}_{t}=0$, what obviously means that the equilibrium price is equal to its fundamental value $\left(s_{f}=\bar{s}\right)$ and expected depreciation of the exchange rate is equal to zero $\left(\dot{r}_{t}=0\right)$. Using graphical perspective the previous system is shown in Figure 1 and Figure 2:

Figure 1: The stable solution with overshooting

$$
(\gamma=0.07, \alpha=0.8, \beta=0.3, \lambda=1.1, s f=11)
$$
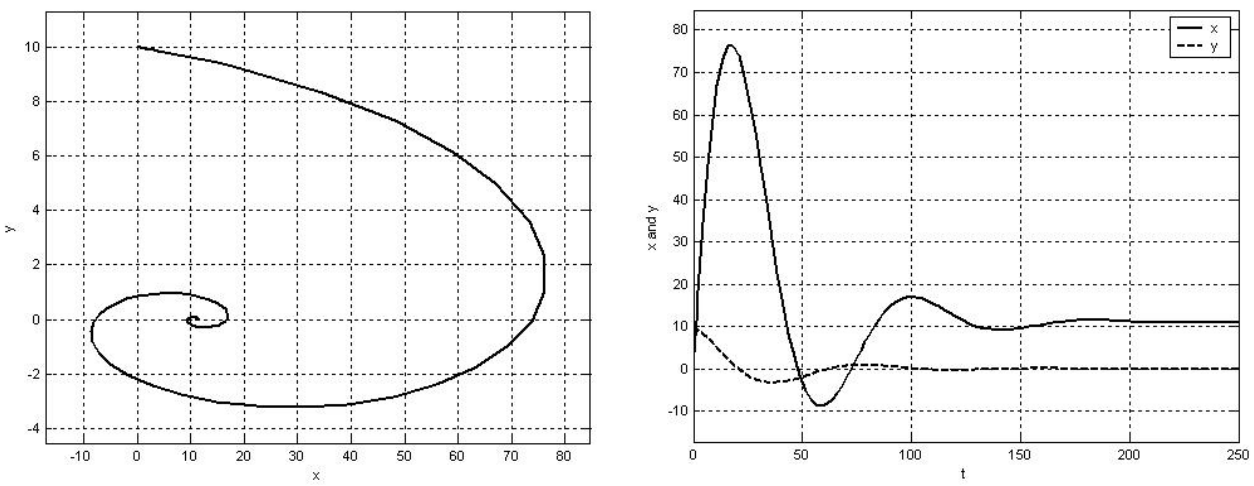

Figure 2: The unstable solution with explosive fluctuations

$$
(\gamma=0.01, \alpha=1, \beta=0.4, \lambda=1.1, s f=10)
$$
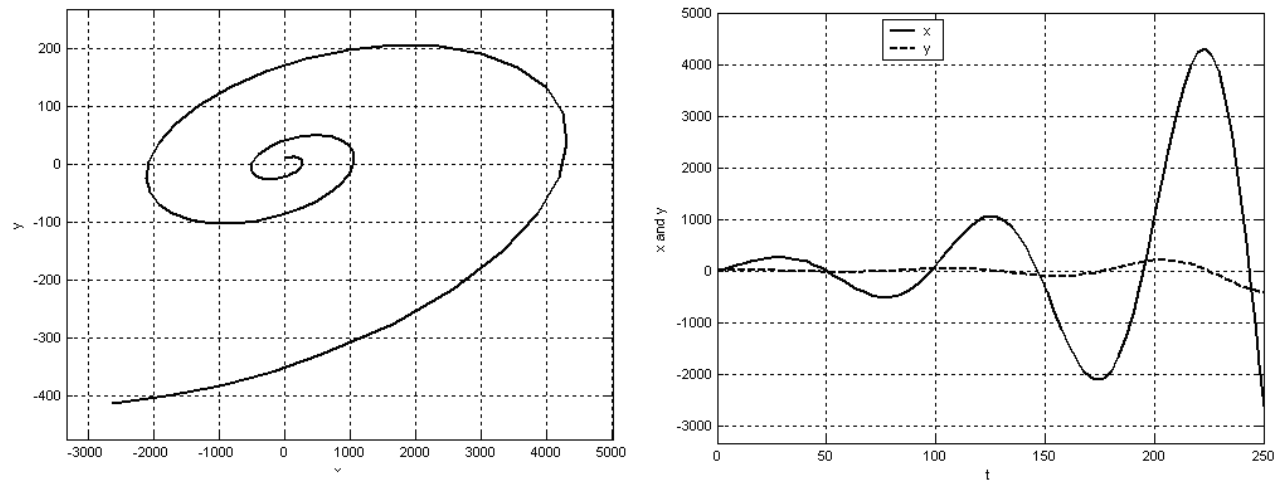

As we can see, this kind of model is able to bear high volatility of exchange rates, as well as the well known Dornbusch-type of overshooting with mean reversion. As for example De Grauwe and M. Grimaldi (2005) have pointed out, models of exchange rate that incorporate heterogeneous beliefs of agents (and therefore nonlinearities in the exchange rate dynamics) are able to explain several puzzles, including the "disconnections" (in all their meanings). They distinguish two agent types: i.e. "chartists" with a positive feedback rule and "fundamentalists" with a negative one. The 
nonlinearities came into the model through the transaction costs and nonlinear adjustment in the goods market. They have shown that the disconnection of actual exchange rate from its long run fundamental value is the natural consequence of nonlinearities in the model. Moreover, the nonlinearity of the model can produce endogenous regime shifts (structural changes) such that the link between the exchange rate and its fundamentals could be broken even when there is no change in the policy regime.

Despite of the promising nature of these kinds of models, their practical usage is quite questionable. As Duarte and Stockman (2005) have pointed out, one should not resign to find explanations of the "disconnect puzzle" within the traditional class of models. The reason is, that you can always build up a model, which is able to explain the data, but there is a question whether the model is able to provide reasonable policy implications.

\section{Conclusions}

The determination of the real and nominal exchange rates is still dominant problem among the monetary economics, especially due to the existence of quite large number of puzzles that the contemporaneous research has been unable to resolve. One of them, the "disconnect puzzle", states that the enormous exchange rate volatility seems to have no corresponding counterpart in the variability of macroeconomic fundamentals. In last few years, researchers are trying to resolve this puzzle together with another "price puzzle" in the international economics, the purchasing power parity puzzle that could be in some sense considered to be a special form of the "disconnect puzzle".

We have shown two possible ways of extending contemporaneous research to resolve the exchange rate disconnect. One based on extending Obstfeld and Rogoff (1995) approach, questioning two competing approaches with nontradables and local currency pricing. The microstructure approach based on heterogeneous agents' expectations has brought another explanation to the exchange rate "disconnect" issue. Another issue that haven't been discussed is the consideration of other type of nonlinear models that are able to capture in some sense the role of deviations from the purchasing power parity. Those models have therefore potential to mimic the real exchange rate behaviour.

In any cases it is worth to say, however, that the role of macroeconomic fundamentals in explaining exchange rate behaviour is undoubtedly controversial and open issue in international macroeconomics.

\section{References}

[1] CAMPBELL, D. (2006). Why Are Exchange Rates Out of Sync With Other Economic Indicators? Region Focus, 2006, vol. 10, no. 1, pp. 29-31.

[2] CHEUNG, Y.; CHINN, M.; PASCUAL, A. G. (2005). Empirical Exchange Rate Models of the Nineties: Are Any Fit to Survive? Journal of International Money and Finance, 2005, vol. 24, no. 7, pp. 1150-1175. 
[3] DE GRAUWE, P.; GRIMALDI, M. (2005). The Exchange Rate and its Fundamentals in a Complex World. Review of International Economics, 2005, vol. 13 , no. 3, pp. 549-575.

[4] DEVEREUX, M. B.; ENGEL, C. (2002). Exchange Rate Pass Through, Exchange Rate Volatility and Exchange Rate Disconnect. Journal of Monetary Economics, 2002, vol. 49, no. 5, pp. 913-940.

[5] DUARTE, M.; STOCKMAN, A. C. (2005). Rational Speculation and Exchange Rate. Journal of Monetary Economics, 2005, vol. 52, no. 1, pp. 3-29.

[6] DUARTE, M. (2001). International Pricing in New Open-Economy Models. Federal Reserve Bank of Richmond Economic Quarterly, 2001, vol. 87, no. 4, pp. 53-70.

[7] ENGEL, C.; WEST, K. D. (2005). Exchange rates and fundamentals. Journal of Political economy, 2005, vol. 113, no. 3, pp. 485-517.

[8] FLOOD, R. P.; ROSE A. K. (1999). Understanding Exchange Rate Volatility without the Contrivance of Macroeconomics. The Economic Journal, 1999, vol. 109, no. 459, pp. 660-672.

[9] FRANKEL, J. A.; FROOT K. A. (1986). Understanding the US Dollar in the Eighties : the Expectations of Chartists and Fundamentalists. The Economic Record, 24-38.

[10] MEESE, R.; ROGOFF, K. (1983). Empirical Exchange Rate Models of the Seventies: Do they Fit Out of sample? Journal of International economics, 1983, vol. 14, no. 1-2, pp. 3-24.

[11] OBSTFELD, M.; ROGOFF, K. (1995). Exchange Rate Dynamics Redux. Journal of Political Economy, 1995, vol.103, no. 3, pp. 624-660.

[12] OBSTFELD, M.; ROGOFF, K. (2000). The Six Major Puzzles in International Macroeconomics: Is there a Common Cause? Washington, D.C. : NBER Working paper no. W7777, 2000.

[13] SARNO, L (2005). Viewpoint: Towards a Solution to the Puzzles in Exchange Rate Economics: Where Do We Stand? Canadian Journal of Economics, 2005, vol. 38, no. 3, pp. 673-708.

\section{Appendix: The Variability of Fundamentals in the CR (1993-2006)}

In following figures we present the behaviour of some major fundamentals in the CR (on monthly basis). The time series are in growth of logarithms and normalized using maximum and minimum of the series. The data are from CNB and Eurostat database. The EUR/CZK time series is the monthly average and the end of the month value. The interest rate time series compares the 3 month Pribor rate for the Czech Republic and 3M eurorate for Euro area. Due to the fact that the output data are not provided on the monthly basis, the seasonally adjusted industry production index is used as a proxy. As a money supply the national defined monetary aggregate M2 is used (the ECB definition aggregates have shorter time series) 
The variability of nominal exchange rate EUR(ECU)/CZK

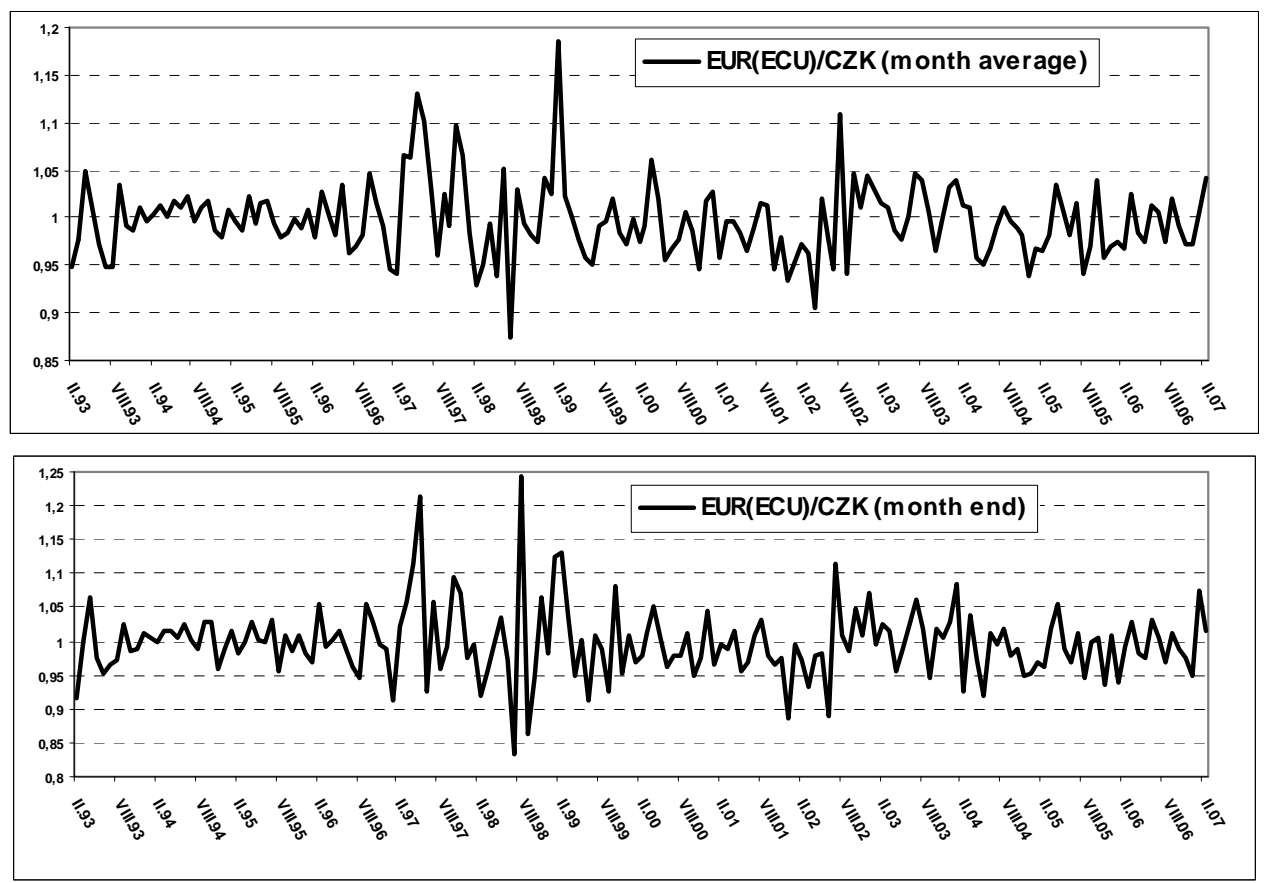

The variability of interest rates and the interest rate differential

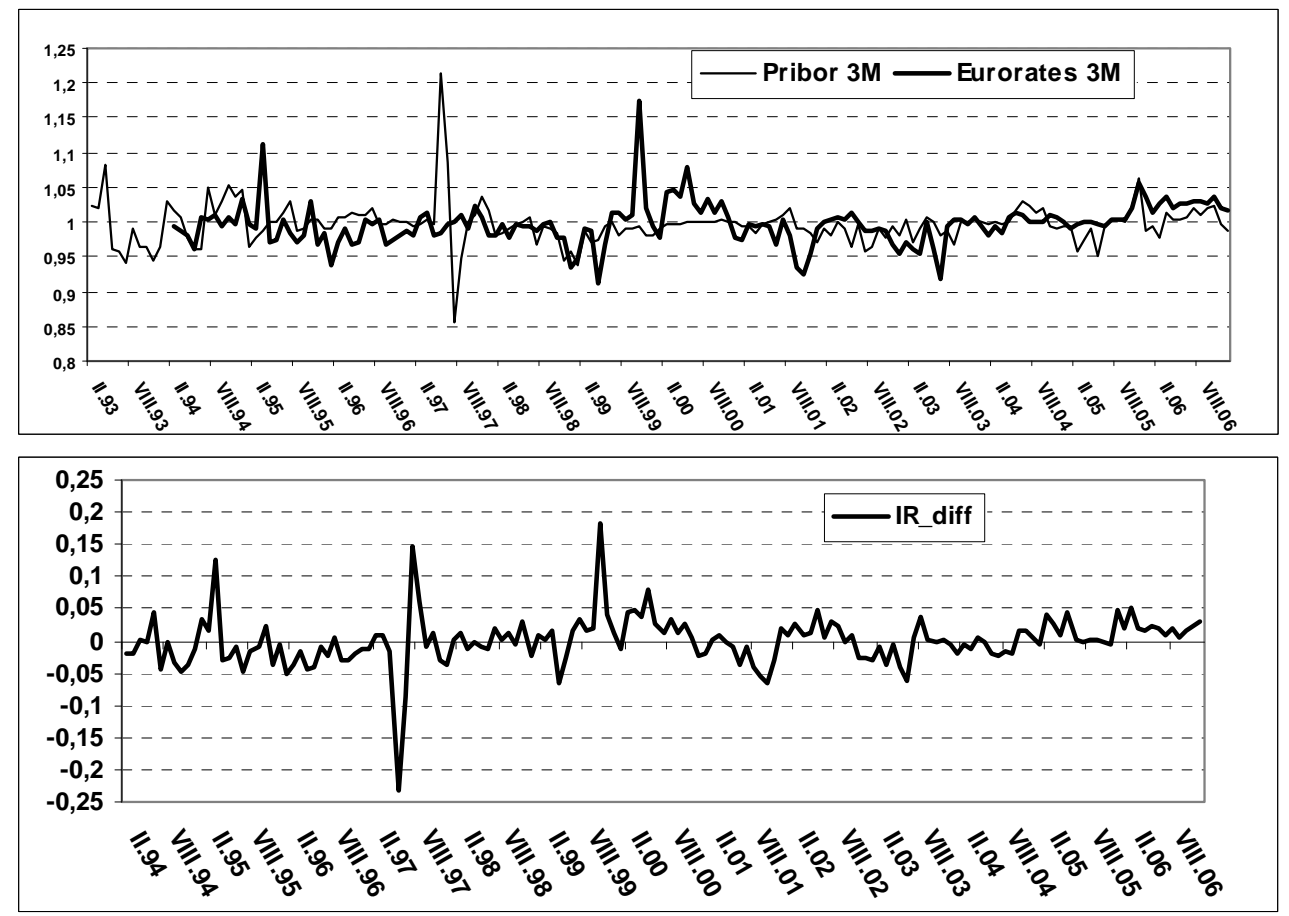


Miroslava Jindrová

Exchange Rate Dynamics and the Disconnect

The variability of industry growth and the industry growth differential
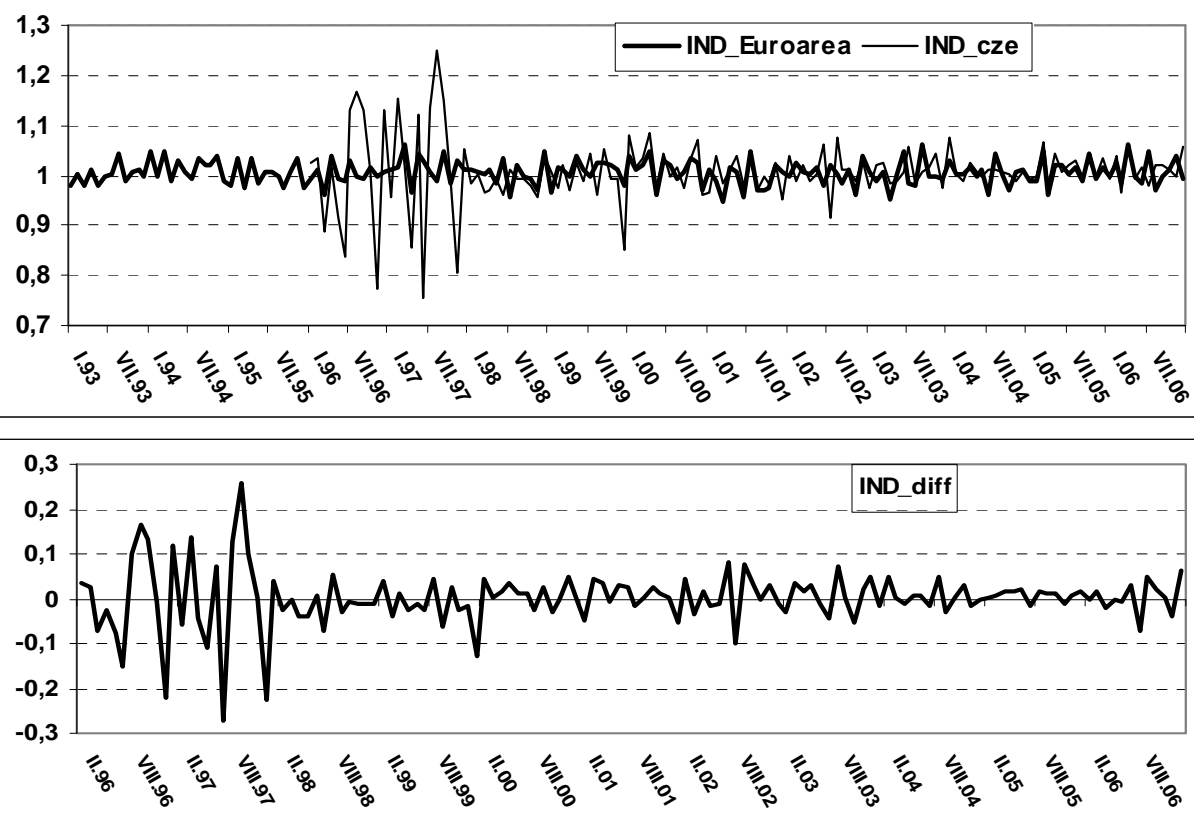

The variability of growth of monetary aggregates and the money growth differential
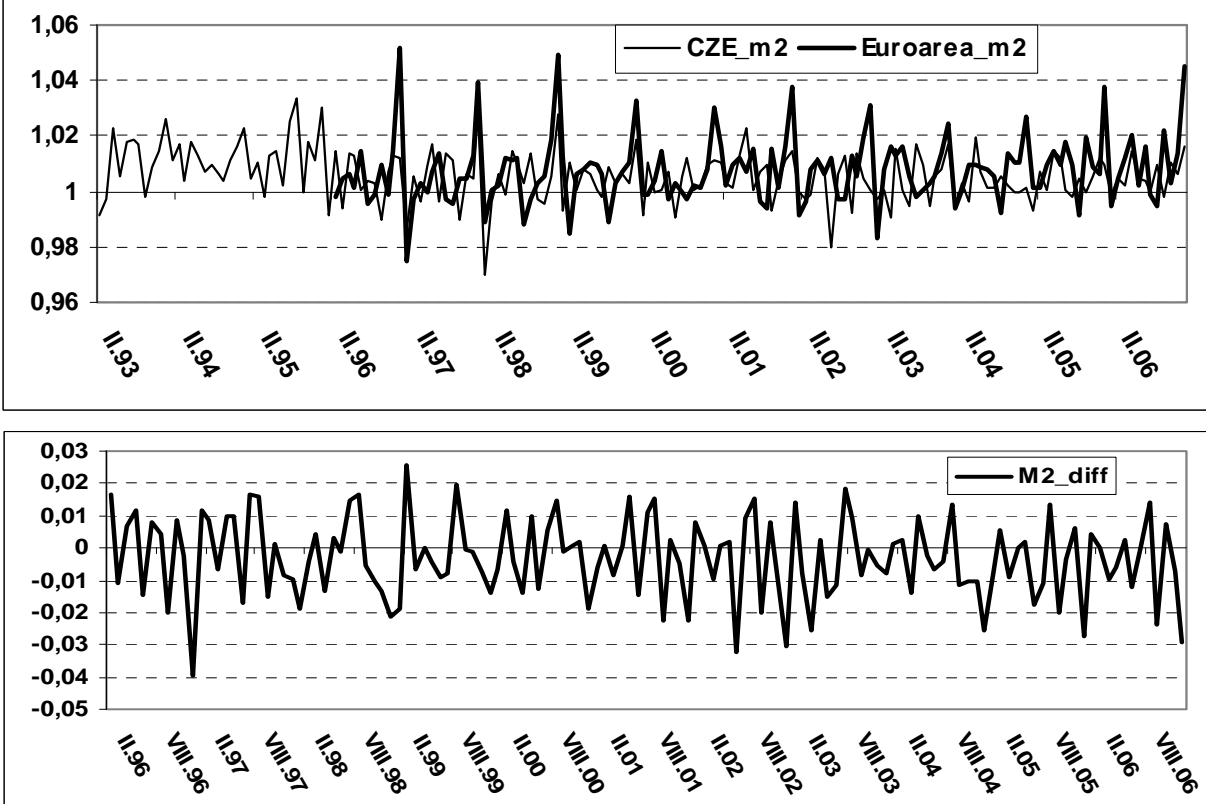

Source: CNB, own computation

67 


\title{
Dynamika devizového kurzu a přerušení vztahu mezi vývojem kurzu a dalších makroekonomických veličin
}

\author{
Miroslava Jindrová
}

\begin{abstract}
Abstrakt
Článek se zabývá problematikou výzkumu determinace devizového kurzu a chybějícího spojení mezi vývojem makroekonomických veličin a devizového kurzu (tzv. "disconnect puzzle". Byly naznačeny směry, jakými se současný výzkum ubírá při řešení a analyzování tohoto problému. Výzkum směřuje do konceptu monopolistické konkurence, $\mathrm{v}$ rámci níž je možné modelovat odchylky devizového kurzu od dlouhodobé fundamentální hodnoty, což umožňuje odklon od platnosti parity kupní síly. Alternativní směr vychází z teorie heterogenních agentů.
\end{abstract}

Klíčová slova: determinace devizového kurzu; disconnect; přestřelování; volatilita.

\section{Exchange Rate Dynamics and the Disconnect}

\begin{abstract}
In this paper we bring the survey of the contemporaneous research on the behaviour of exchange rate and so called exchange rate disconnect puzzle. We have introduced several directions in which research on this object could be developed. They are basically concerned with the monopolistically competition, which allows for exchange rate fluctuations from its long run equilibrium level, so that purchasing power parity condition doesn't holds. The alternative approach incorporates heterogeneous agents' setup.
\end{abstract}

Key words: exchange rate determination; exchange rate disconnect; overshooting; volatility.

JEL classification: E52, F31, F41. 